\title{
Synergistic Disparities and Public Health Mitigation of COVID-19 in the Rural United States
}

\author{
Kata L. Chillag • Lisa M. Lee
}

Received: 15 May 2020 / Accepted: 21 September 2020

(C) Journal of Bioethical Inquiry Pty Ltd. 2020

\begin{abstract}
Public health emergencies expose social injustice and health disparities, resulting in calls to address their structural causes once the acute crisis has passed. The COVID-19 pandemic is highlighting and exacerbating global, national, and regional disparities in relation to the benefits and burdens of undertaking critical basic public health mitigation measures such as physical distancing. In the United States, attempts to address the COVID-19 pandemic are complicated by striking racial, economic, and geographic inequities. These synergistic inequities exist in both urban and rural areas but take on a particular character and impact in areas of rural poverty. Rural areas face a diverse set of structural challenges, including inadequate public health, clinical, and other infrastructure and economic precarity, hampering the ability of communities and individuals to implement mitigation measures. Public health ethics demands that personnel address both the tactical, real-time adjustment of typical mitigation tools to improve their effectiveness among the rural poor as well as the strategic, longerterm structural causes of health and social injustice that continue to disadvantage this population.
\end{abstract}

\footnotetext{
K. L. Chillag ( $\bowtie)$

Davidson College, Box 7135, 405 N Main Street, Davidson, NC 28035, USA

e-mail: kachillag@davidson.edu

L. M. Lee

Virginia Tech, Scholarly Integrity and Research Compliance and Department of Population Health Sciences, North End Center, Suite 4120 (0497), 300 Turner St NW, Blacksburg, VA 24061, USA

e-mail:1mlee@vt.edu
}

Keywords Public health ethics · Rural health - Justice · Equity $\cdot$ Health disparities

\section{Introduction}

As of September 2020, confirmed COVID-19 cases and deaths in the United States were approaching 7 million and 200,000 respectively (Johns Hopkins University and Medicine 2020). Initially concentrated in urban centres, rural areas in the United States began to experience faster case and mortality growth as the epidemic progressed (Fehr et al. 2020; Johns Hopkins University and Medicine 2020). While rural areas are not homogenous, many rural counties in the United States are poorer than their urban counterparts. Rural areas also have more fragile public health and clinical infrastructure, and an older and less healthy population more vulnerable to COVID-19 (Ajilore 2020; Ameh et al. 2020; Bolin et al. 2015; Gong et al. 2019; Gurley 2016; NORC at the University of Chicago Walsh Center for Rural Health Analysis 2012).

In this analysis, we describe how synergistic disparities in rural areas, particularly areas of rural poverty, affect the effectiveness of key public health mitigation measures: disease surveillance, physical distancing, hand and respiratory hygiene, and public health communication. We focus on how these disparities complicate the implementation of public health mitigation measures in rural areas. We recognize that some features of rurality might promote successful implentation of certain mitigation measures, such as 
physical distancing and the use of outdoor space as a less-risky alternative to essential gatherings, however, there are many features of rural life that make managing a highly contagious, novel pathogen more challenging. Public health ethics, with its commitments to justice, solidarity, and efficiency, demands that governments and public health institutions take actions to adapt typical mitigation tools to improve their effectiveness during the current pandemic, address the immediate burdens they place on the vulnerable, and reduce the structural determinants of health generally in rural areas in the United States.

\section{Basic Public Health Mitigation Measures}

Basic public health mitigation strategies are critical to addressing infectious disease epidemics, particularly when we are confronted with a novel pathogen and few biomedical countermeasures are available (Guest, Del Rio, and Sanchez 2020; Lewnard and Lo 2020; Peak et al. 2017; World Health Organization 2020; World Health Organization Writing Group 2006). Central to public health mitigation is disease surveillance, which comprises the systematic collection and analysis of information about disease incidence, prevalence, and risk factors for public health action (Lee et al. 2010). Without effective surveillance, it is difficult to make effective policy or strategically deploy measures such as physical distancing and requirements for face coverings (Wallinga, van Boven, and Lipsitch 2010). COVID-19 surveillance in the United States remains hamstrung by several factors, including uncoordinated and incomplete data collection and insufficient and inequitable testing (Peake, Ravikumar, and Vandenbroucke 2020).

Physical distancing measures include a range of practices such as school and business closures, restrictions on the size of indoor gatherings, self-quarantine, and isolation. These measures are controversial because they raise tensions between individual freedoms and public goods, place disproportionate burdens on persons with few resources and other vulnerabilities, and can be abused because they involve restriction of civil liberties (Barbisch, Koenig, and Shih 2015; Rothstein 2015; Upshur 2003; Wynia 2007).

Hand and respiratory hygiene includes handwashing and mask use (World Health Organization 2020). Often highly effective when done correctly, even seemingly straightforward measures like wearing face coverings can present practical and ethical challenges. For example, African-American men have expressed fear that wearing masks could make them the target of police harassment (Taylor 2020).

Effective public health communication requires translation of complex and changing information into messages that foster trust and promote action among diverse audiences. In a crisis, public health education and communication professionals must disseminate rapidly changing information and counter misinformation in a climate of scepticism, fear, and politicization.

Though many public health mitigation measures seem simple, they demand considerable material and human resources, from information technology to legions of contact tracers. Because their success rests on public trust and involves extraordinary burdens and intrusions, the design and implementation of public health measures must be shaped by understanding of sociocultural, economic, geographic, and political contexts in which they take place.

\section{Synergistic Disparities, Rural Poverty, and Public Health Mitigation Measures}

Overlapping demographic, economic, and health vulnerabilities characterize rural areas in the United States. Inadequate public health infrastructure and poor health in the rural southern "Black Belt," for example, are shaped by longstanding racial and economic disparities (Harris 2020; Warren and Tarver 2010). Lack of basic services as well as poor educational and economic opportunities for Native Americans, especially in the rural Middle West, reflect longstanding economic and resource disparities imposed by federal policy since the founding of the United States. The dramatic disparities in many rural communities are the result of long-term discriminatory policies and a failure to see programmes through to reach U.S. residents with the least social capital. Other vulnerabilities in rural areas are exacerbated by the interdependence of rural and urban areas, such as affluent city dwellers migrating to rural areas to avoid transmission (Bellafante 2020). While this might benefit rural economies, this migration presents increased risk of infection for rural residents and places strain on its limited public health and clinical infrastructure (Kelman and Dodds 2009; Peterson 2020). 
Rural occupational patterns, including dominance of low-wage jobs in essential industries, place persons at higher risk of contracting SARS-CoV-2 and less able to comply with physical distancing (Ajilore and Willingham 2019; Burdorf, Porru, and Rugulies 2020; Liu et al. 2019). Often located in rural areas and frequently staffed by immigrants facing additional barriers to advocating for safe work conditions, meat processing facilities have emerged as loci of SARS-CoV-2 infection (Artz 2012; Dyal et al. 2020). The crowded nature of the work facilitates transmission (KyerematengAmoah et al. 2014). Agricultural supply-chain pressure to maintain normal operations hampers adoption of recommended public health mitigation measures such as permissive sick leave (Dyal et al. 2020; Jimenez 2020).

The population of rural areas is, on average, older, with more of its residents at higher risk of COVID-19 complications (CDC COVID-19 Response Team 2020; Garcia et al. 2017). High rates of comorbidities, such as diabetes and heart disease, argue for stringent implementation of basic public health measures. Other common co-morbidities such as depression and addiction require additional attention to how physical distancing impacts mental health and well-being (Panchal et al. 2020; NORC at the University of Chicago Walsh Center for Rural Health Analysis 2017).

The nature of older age in areas of rural poverty complicates public health mitigation efforts. In Appalachia, for example, many persons are custodial grandparents, in part due to the opioid epidemic (Phillips and Alexander-Eitzman 2016). Vulnerable children in the care of grandparents can be made more so by social mitigation measures. Children in rural poverty and in the care of custodial grandparents are frequently food insecure and dependent on meals at school (Freeman 2019). In addition, their home environments might not be conducive to virtual schooling due to lack of access to highspeed broadband internet (Anderson 2018).

Adequate housing and sanitation are important for the implementation of mitigation measures. Hand hygiene relies on plumbing and water infrastructure. Substandard plumbing and lack of access to clean, potable water is more common in rural areas and is especially prevalent in parts of the southern Black Belt, and among Native American and migrant communities (Bischoff et al. 2012; Gasteyer et al. 2016; VanDerslice 2011; Wedgworth and Brown 2013). Recent data estimate that Native American households are nineteen times more likely to lack indoor plumbing compared with their white counterparts (U.S. Water Alliance 2019). Insecure housing and crowding within households, also common, increases the possibility of SARS-CoV-2 transmission and reduces options for effective selfquarantine (National Rural Housing Coalition 2020; Ungar and Lucas 2020).

The geography and population density of rural areas creates logistical barriers for basic public health mitigation measures such as diagnostic testing and contact tracing (Johns Hopkins University and Medicine 2020). Coupled with inconsistent policy, incomplete information, and messages that underplay the scope and severity of the pandemic, at times drawing from politicized rhetoric pitting the interests of rural and urban areas against each other, the delayed health impact on rural areas can diminish political will for mitigation measures and public perception of their necessity (Berube 2016; Brownstein 2020). The often-disproportionate economic impact of the pandemic on rural areas relative to its perceived health effects intensifies pressure to push back against public health measures (Crampton and McCrimmon 2020; Melillo 2020). With inadequate federal leadership and assistance, obtaining and equitably allocating commodities such as personal protective equipment and testing components, responsibility for addressing the pandemic has fallen to local jurisdictions. States and localities have been forced to compete for resources, dependent on their ability to advocate for themselves (Court and Carville 2020). This is especially difficult for rural areas without the resources or ability to engineer alternative strategies to determine or meet their needs.

Several features of public health and health care infrastructure present challenges. Rural health departments often have fragile financial, human, information technology, and laboratory infrastructure (NORC at the University of Chicago Walsh Center for Rural Health Analysis 2012). They often perform less well in relation to core public health functions under non-emergency circumstances, including addressing disparities (Harris et al. 2016; Newman et al. 2014). There are often fewer relevant specialists among the staff, such as epidemiologists and statisticians (Jones et al. 2015; Santibañez et al. 2019). Hospital closures and shortage of health care providers result in similar resource challenges in clinical settings, which are also critical to pandemic response (Skinner et al. 2019). The increasing shortage of health professionals specializing in primary care in the United 
States is particularly acute in rural areas and has disproportionate impact in relation to the demographic and health characteristics of underserved rural populations, referral for testing, and public health education. The promise of telemedicine and other virtual technology is encouraging, but technological, educational, and other barriers must be remediated for these technologyenhanced services to be effective (Nouri et al. 2020; Ohannessian 2015; Weinstein et al. 2014). Long-term care facilities, which have been a locus of COVID-19 cases, are of additional concern in rural areas because of limited staffing, funding models, infection control practices, and patient demographics (Bowblis et al. 2013; Kang, Meng, and Miller 2011; Ye et al. 2015).

\section{Ethical Demands of Public Health Practice During and After an Outbreak}

The ethical demands of public health practice in rural areas are substantial during and after a public health emergency. As public health expands into its third major phase of practice, in which it prioritizes social determinants of health and works closely with an increasingly diverse set of stakeholders to promote human flourishing, the moral obligations to social justice become increasingly visible (DeSalvo et al. 2017; Lee et al. 2020; Lee 2012). This professional responsibility requires public health to address synergistic disparities on two levels. The tactical level comprises immediate efforts necessary to address the public health problem in front of us, while the strategic level demands that we attend to the underlying structural causes of health and social injustice after the crisis subsides.

In the throes of the COVID-19 pandemic, tactical efforts are central to containing a highly contagious, lethal pathogen with a limited set of public health tools. The ethical underpinnings of public health emergency response reinforce the moral urgency of both the tactical examination of the uneven impact of the outbreak on vulnerable communities as well as the creation of customized, equitable solutions (American Public Health Association [APHA] 2019; Jennings and Arras 2016).

The American Public Health Association (2019) outlines core values that undergird the profession, and ethical considerations that should guide public health decision-making (see table 1).
Assuming that all six core values and eight ethical considerations apply to public health work in every community, the core values of health justice and equity as well as interdependence and solidarity obligate public health professionals to focus their work on populations experiencing synergistic disadvantage. The ethical considerations of respect, reciprocity, and effectiveness obligate us to alter prevention measures to meet the specific needs of rural populations.

As core public health values, health justice, and equity obligate public health professionals to secure opportunities for health among all communities, especially those who, by virtue of systemic inequities, are less likely to achieve health status equal to persons with social and economic privilege. Similarly, interdependence and solidarity, or the recognition that the health of every individual is linked to the health of every other individual in a community, requires that public health officials effectively mitigate harms to all community members, adjusting interventions to ensure that all affected members can effectively participate. Reciprocity requires public health organizations to provide reasonable resources to allow community members to effectuate the required public health measures.

Public health professionals must consider ways to make disease surveillance, public health education, and physical distancing achievable in rural areas. Testing is critical to public health surveillance, but SARSCoV-19 testing in rural areas remains limited and in many cases is offered only at central testing sites for symptomatic individuals or patients with referrals from their healthcare provider. For rural residents, this model

Table 1 Public health core values and ethical considerations (APHA 2019)

Core Public Health Values Ethical Considerations for Decision Making

\begin{tabular}{ll}
\hline Professionalism and trust & Permissibility \\
Health and safety & Respect \\
$\begin{array}{l}\text { Health justice and equity } \\
\text { Interdependence and } \\
\text { solidarity }\end{array}$ & Reciprocity \\
$\begin{array}{c}\text { Human rights and civil } \\
\text { liberties }\end{array}$ & Responsible use of scarce resources \\
$\begin{array}{c}\text { Inclusivity and } \\
\text { engagement }\end{array}$ & Proportionality \\
& Accountability and transparency \\
& Public participation \\
\hline
\end{tabular}


breaks down due to transportation challenges and an inadequate healthcare system. To make this testing model tenable in rural areas, public health officials cannot rely solely on residents to come to a testing site. Once testing capacity is increased, partnering with grocery stores or pharmacies for onsite testing, home-based testing, and provision of transportation could improve uptake.

Similarly, physical distancing can present extenuating challenges for rural residents. For exposed residents to remain in self-quarantine or isolation, public health officials must find ways to support rural families that are unable to afford dwellings with separate bedrooms and bathrooms or obtain food for their families. While charitable organizations offer some assistance, to support effective self-quarantine and isolation, a person needs separate space, as well as a way to acquire food without leaving their dwelling. To address this, public health officials need to consider adding housing and food support, as well as child- and eldercare resources to their mitigation strategies.

Delivering effective public health communication in the midst of rapidly changing evidence and abundant misinformation is a major public health challenge. News and information consumption has changed dramatically with social media and smart phones, though in rural areas access to even these resources reflect a digital divide. Headlines, which are often the only part of an article that is read, have always tended toward the inflammatory and are now more explicitly designed as revenue-generating "clickbait." Rural media resources, with increasingly fewer local news institutions and insufficient coverage of rural communities and the issues relevant to them, including public health, further complicate effective communication (Grieco 2019; Thielman, Civeris, and Rashidian 2020). A challenging tactical question for rural public health is how to engage communities to increase trust so evidence-based public health messages do not fade in to a sea of competing claims. Building trust takes time and positive engagement. It can start by identifying community opinion leaders who are willing to work closely with public health officials to create and communicate accurate and accessible messages. It also includes engagement with media to advocate for accurate coverage of public health issues in rural areas.

Once the COVID-19 pandemic subsides, our strategic work must begin. We must meet our ethical obligation to remedy the synergistic disparities that place the rural poor at systemic disadvantage during and after public health emergencies. The moral imperative to advocate for a just system of opportunities for health is woven into the fabric of public health ethics. Often public health officials consider ways to ensure that interventions do not exacerbate disparities, but here we are pointing to the moral obligation that calls for purposeful, persistent efforts to reduce health inequities, bringing the evidence-based, action-oriented field of twenty-first century public health back to its inclusive, social justice roots.

Public health organizations cannot address the structural causes of systemic disadvantage alone. To attend to such broad health impacts as education, economic and housing insecurity, racism and xenophobia, persistent poverty, basic sanitation, and access to prevention and healthcare services, public health officials must embrace a new role as a coordinator of health influences. DeSalvo et al. (2017), described the role as "chief health strategist" to drive collective action, including coordinated policymaking to address the interdependence of policy in disparate domains that affect health-immigration, housing, health insurance coverage, distribution of medical care providers, education, and transportation, among others. Public policy is an essential tool of public health, stemming from agreement among all the major theories of political philosophy that it is important for governments to improve the lives of the least well-off (Wolff 2009). If we agree that it is in the best interests of the state to meet the basic needs of the least advantaged, then it is incumbent upon us to work together to meet basic needs of the disadvantaged, in this case, the rural poor.

In their description of ethics of public health emergency response, Jennings and Arras formulated a "civic perspective" view (Jennings and Arras 2016, 10) of what ought to motivate public health professionals and organizations during emergency response. They describe this perspective as motivation for engagement stemming from common interests and community membership, and as a force for social change. They state, “... public health leadership can move communities beyond [fear and self-interest] to a sense of common purpose and solidarity" (Jennings and Arras 2016, 12). We are suggesting that not only can public health leadership move communities toward common purpose and solidarity but that they have a professional moral obligation to do so. It is this civic perspective along with a focus on community resilience and empowerment that obligates 
both public health professionals and societies to attend to the strategic pieces following a public health emergency response.

Jennings and Arras's focus on community resilience and empowerment should not, however, imply that a community faced with persistent, synergistic disadvantage only need pull itself up by its bootstraps or that attention to public health will empower a community. Advantaged and privileged communities must attend to their role in creating, and importantly, in deconstructing the structural causes of persistent disadvantage.

\section{Conclusion}

"The virus does not discriminate" has been an oftrepeated refrain during the COVID-19 pandemic, mostly well-intended to encourage vigilance and attempt to mitigate stigma and racism. This message obscures the ways that public health emergencies are shaped and exacerbated by social injustice and synergistic disparities. The shape of the pandemic is in fact profoundly discriminatory, as are most public health emergencies, bringing once again into stark relief the differences in access to critical public goods. Public health ethics has long recognized the moral obligation to adapt interventions to meet the needs of all communities. The COVID19 pandemic has reminded us to attend to the longerterm strategic efforts to right the persistent inequities and create more equitable conditions even after the public health emergency subsides.

\section{References}

Ajilore, O. 2020. Rural America is starting to feel the impact of the coronavirus. Center for American Progress, April 28. https://www.americanprogress.org/issues/ ?economy/reports/2020/04/28/484016/rural-americastarting-feel-impact-coronavirus/. Accessed May 13, 2020.

Ajilore, O., and Z. Willingham. 2019. Adversity and assets: Identifying rural opportunities. Center for American Progress, October 21. https://www.americanprogress. org/issues/economy/reports/2019/10/21/476097/adversityassets-identifying-rural-opportunities/. Accessed May 14, 2020.

Ameh, G.G., A. Njoku, J. Inungu, and M. Younis. 2020. Rural America and coronavirus epidemic: Challenges and solutions. European Journal of Environment and Public Health 4(2): em0040.

American Public Health Association (APHA). 2019. Public Health Code of Ethics. APHA: Washington DC.
Anderson, M. 2018. About a quarter of rural Americans say access to high-speed internet is a major problem. Pew Research Center: Fact Tank, September 10. https://www.pewresearch. org/fact-tank/2018/09/10/about-a-quarter-of-rural-americanssay-access-to-high-speed-internet-is-a-major-problem/. Accessed May 15, 2020.

Artz, G.M. 2012. Immigration and meatpacking in the Midwest. Choices 27(2): 1-5.

Barbisch, D., K.L. Koenig, and F.Y. Shih. 2015. Is there a case for quarantine? Perspectives from SARS to Ebola. Disaster Medicine and Public Health Preparedness 9(5): 547-553.

Bellafante, G. 2020. The rich have a Coronavirus cure: Escape from New York. The New York Times, March 14. https://www. nytimes.com/2020/03/14/nyregion/Coronavirus-nyc-richwealthy-residents.html. Accessed May 14, 2020.

Berube, A. 2016. Political rhetoric exaggerates economic divisions between rural and urban America. Brookings, August 16. https://www.brookings.edu/blog/the-avenue/2016/08/03 /political-rhetoric-exaggerates-economic-divisions-betweenrural-and-urban-america/. Accessed May 15, 2020.

Bischoff, W.E., M. Weir, P. Summers, et al. 2012. The quality of drinking water in North Carolina farmworker camps. American Journal of Public Health 102(10): e49-e54.

Bolin, J.N., G.R. Bellamy, A.O. Ferdinand, et al. 2015. Rural healthy people 2020: New decade, same challenges. The Journal of Rural Health 31(3): 326-333.

Bowblis, J.R., H. Meng, and K. Hyer. 2013. The urban-rural disparity in nursing home quality indicators: The case of facility-acquired contractures. Health Services Research 48(1): 47-69.

Brownstein, R. 2020. Red and blue America aren't experiencing the same pandemic. The Atlantic, March 22. https://www. theatlantic.com/politics/archive/2020/03/how-republicansand-democrats-think-about-coronavirus/608395/. Accessed May 15, 2020.

Burdorf, A., F. Porru, and R. Rugulies. 2020. The COVID-19 (coronavirus) pandemic: Consequences for occupational health. Scandinavian Journal of Work, Environment \& Health 46(3): 229-230.

CDC COVID-19 Response Team. 2020. Severe outcomes among patients with coronavirus disease 2019 (COVID-19)United States, February 12-March 16, 2020. Morbidity and Mortality Weekly Report 69(12): 343-346.

Court, E., and O. Carville. 2020. Virus test shortages undermine drive to restart U.S. economy. Bloomberg, April 28. https:/www.bloomberg.com/news/articles/2020-04-28 /virus-testing-shortages-undermine-drive-to-restart-u-seconomy. Accessed May 15, 2020.

Crampton, L., and R. McCrimmon. 2020. "This will be a wallop": Rural areas brace for hard economic hit. Politico, March 26. https://www.politico.com/news/2020/03/26/rural-areascoroanvirus-economy-149218. Accessed May 15, 2020.

DeSalvo, K.B., Y.C. Wang, A. Harris, J. Auerbach, D. Koo, and P. O'Carroll. 2017. Public health 3.0: A call to action for public health to meet the challenges of the 21 st century. Preventing Chronic Disease 14: 170017.

Dyal J.W., M.P. Grant, K. Broadwater, et al. 2020. COVID-19 among workers in meat and poultry processing facilities - 19 states, April 2020. Morbidity and Mortality Weekly Report 69(18): 557-561. 
Fehr, R., J. Kates, C. Cox, and J. Michaud. 2020. COVID-19 in rural America-is there cause for concern? KFF, April 30. Last modified April 20, 2020. https://www.kff. org/coronavirus-covid-19/issue-brief/covid-19-in-ruralamerica-is-there-cause-for-concern/. Accessed May 13, 2020.

Freeman, A. 2019. 5 grandparents tell FRAC and Generations United how the Federal Nutrition Programs help feed grandfamilies. Food Research \& Action Center, October 11. https://frac.org/blog/5-grandparents-tell-frac-andgenerations-united-how-the-federal-nutrition-programshelp-feed-grandfamilies. Accessed May 15, 2020.

Garcia, M. C., M. Faul, G. Massetti, et al. 2017. Reducing potentially excess deaths from the five leading causes of death in the rural United States. MMWR Surveillance Summaries 66(2): 1 .

Gasteyer, S.P., J. Lai, B. Tucker, J. Carrera, and J. Moss. 2016. Basics inequality: Race and access to complete plumbing facilities in the United States. Du Bois Review 13(2): 305325.

Gong, G., S.G. Phillips, C. Hudson, D. Curti, and B.U. Philips. 2019. Higher US rural mortality rates linked to socioeconomic status, physician shortages, and lack of health insurance. Health Affairs 38(12): 2003-2010.

Grieco, E. 2019. For many rural residents in U.S., local news media mostly don't cover the area where they live. Pew Research Center, April 12. https://www.pewresearch. org/fact-tank/2019/04/12/for-many-rural-residents-in-u-slocal-news-media-mostly-dont-cover-the-area-where-theylive/. Accessed June 29, 2020.

Guest, J. L., C. Del Rio, and T. Sanchez. 2020. The three steps needed to end the COVID-19 pandemic: Bold public health leadership, rapid innovations, and courageous political will. JMIR Public Health and Surveillance 6(2): e19043.

Gurley, L. 2016. Who's afraid of rural poverty? The story behind America's invisible poor. American Journal of Economics and Sociology 75(3): 589-604.

Harris, A. 2020. Rural southerners take on the coronavirus. The Atlantic, May 7. https://www.theatlantic.com/politics/archive /2020/05/coronavirus-rural-south/610963/. Accessed May 14, 2020.

Harris, J.K., K. Beatty, J.P. Leider, A. Knudson, A., B.L. Anderson, and M. Meit. 2016. The double disparity facing rural local health departments. Annual Review of Public Health 37(1): 167-184.

Jennings, B., and J.D. Arras. 2016. Ethical aspects of public health emergency preparedness and response. In Emergency ethics: Public health preparedness and response, edited by B. Jennings, J.D. Arras, D.H. Barrett, and B.A. Ellis. New York: Oxford University Press.

Jimenez, M. 2020. How COVID-19 affects farmers and the food supply chain. Tufts Now, April 27. https://now.tufts. edu/articles/how-covid-19-affects-farmers-and-food-supplychain. Accessed May 14, 2020.

Johns Hopkins University and Medicine. 2020. Coronavirus resource center. Last modified June 28. https://coronavirus.jhu. edu/us-map. Accessed June 28, 2020.

Jones, J.A., L. Banks, I. Plotkin, S. Chanthavongsa, and N. Walker, N. 2015. Profile of the public health workforce: Registered TRAIN learners in the United States. American Journal of Public Health 105(S2): e30-e36.
Kang, Y., H. Meng, and N.A. Miller. 2011. Rurality and nursing home quality: Evidence from the 2004 National Nursing Home Survey. The Gerontologist 51(6): 761-773.

Kelman, I., and R. Dodds. 2009. Developing a code of ethics for disaster tourism. International Journal of Mass Emergencies and Disasters 27(3): 272-296.

Kyeremateng-Amoah, E., J. Nowell, A. Lutty, P.S.J. Lees, and E.K. Silbergeld. 2014. Laceration injuries and infections among workers in the poultry processing and pork meatpacking industries. American Journal of Industrial Medicine 57(6): 669-682.

Lee, L.M., S.M. Teutsch, S.B. Thacker, and M.E. St. Louis. 2010. Principles and practice of public health surveillance. Oxford University Press, USA.

Lee, L.M. 2012. Public health ethical theory: Review and path to convergence. The Journal of Law, Medicine \& Ethics 40(1): 85-98.

Lee L.M., S.E. Ortiz, G. Pavela, and B. Jennings. 2020. Public health code of ethics: Deliberative decision-making and reflective practice. American Journal of Public Health 110(4): 489-491.

Lewnard, J.A., and N. Lo. 2020. Scientific and ethical basis for social-distancing interventions against COVID-19. The Lancet Infectious Diseases 20(6): 631-633.

Liu, P., P. Nunn, J. Parsons, and J. Shambaugh. 2019. Has job growth reached America's struggling places? Brookings Up Front, March 7. https://www.brookings.edu/blog/upfront $/ 2019 / 03 / 07 /$ has-job-growth-reached-americasstruggling-places/. Accessed May 14, 2020.

Melillo, G. 2020. Pandemic brings racial, economic, and healthcare disparities into focus. AJMC Peer Exchange, April 6. https://www.ajmc.com/focus-of-the-week/pandemic-bringsracial-economic-healthcare-disparities-into-focus. Accessed May 15, 2020.

National Rural Housing Coalition. 2020. Housing need in rural America. https://ruralhousingcoalition.org/overcomingbarriers-to-affordable-rural-housing/. Accessed May 15, 2020.

Newman, S.J., J. Ye, and C.J. Leep. 2014. Workforce turnover at local health departments: Nature, characteristics, and implications. American Journal of Preventive Medicine 47(5): S337-S343.

NORC at the University of Chicago Walsh Center for Rural Health Analysis. 2017. Appalachian diseases of despair. https://www. arc.gov/assets/research_reports/AppalachianDiseases ofDespairAugust2017.pdf. Accessed May 15, 2020.

NORC at the University of Chicago Walsh Center for Rural Health Analysis. 2012. Establishing and maintaining public health infrastructure in rural communities. https://www.norc. org/PDFs/Walsh\%20Center/NRHA_FinalReport_4\%2027 $\% 2012$ FINAL\%20(2).pdf. Accessed May 14, $20 \overline{20}$.

Nouri, S., E.C. Khoong, C. Lyles, and L. Karliner. 2020. Addressing equity in telemedicine for chronic disease management during the Covid-19 pandemic. NEJM Catalyst, May 4. https://doi.org/10.1056/CAT.20.0123

Ohannessian, R., 2015. Telemedicine: Potential applications in epidemic situations. European Research in Telemedicine 4(3): 95-98.

Panchal, N., R. Kamal, K. Orgera, et al. 2020. The implications of COVID-19 for mental health and substance use. $K F F$, April 21. https://www.kff.org/coronavirus-covid-19/issue- 
brief/the-implications-of-covid-19-for-mental-health-andsubstance-use/. Accessed May 15, 2020.

Peak, C.M., L.M. Childs, Y.H. Grad, and C.O Buckee. 2017. Comparing nonpharmaceutical interventions for containing emerging epidemics. Proceedings of the National Academy of Sciences 114(15): 4023-4028.

Peake, M., B. Ravikumar, and G. Vandenbroucke. 2020. The lost weeks of COVID-19 testing in the United States: Part II. Economic Synopses, no. 25. https://research.stlouisfed. org/publications/economic-synopses/2020/04/23/the-lostweeks-of-covid-19-testing-in-the-united-states-part-ii. Accessed May 15, 2020.

Peterson, A.H. 2020. The pandemic is not your vacation. Buzzfeed News, March 31. https:/www.buzzfeednews.com/article/ annehelenpetersen/coronavirus-covid-cities-second-homesrural-small-towns. .

Phillips, D.L., and B. Alexander-Eitzman. 2016. Intersections of poverty, geography, and custodial grandparent caregiving in Appalachia. GrandFamilies 3(1): 3.

Rothstein, M.A. 2015. From SARS to Ebola: Legal and ethical considerations for modern quarantine. Indiana Health Law Review 12(1): 227-280.

Santibañez, S., K.S. Bellis, A. Bay, et al. 2019. Strengthening rural states' capacity to prepare for and respond to emerging infectious diseases, 2013-2015. Southern Medical Journal 112(2): 101-105.

Skinner, L., D.O. Staiger, D.I. Auerbach, and P.I. Buerhaus. 2019. Implications of an aging rural physician workforce. The New England Journal of Medicine 381(4): 299-301.

Taylor, D.B. 2020. For black men, fear that masks will invite racial profiling. The New York Times, April 14. https://www. nytimes.com/2020/04/14/us/coronavirus-masks-racismafrican-americans.html. Accessed May 15, 2020.

Thielman, S., G. Civeris, and N. Rashidian. 2020. The Tow Center COVID-19 Newsletter: Rural health coverage. Columbia Journalism Review, April 28. https://www.cjr.org/tow center/the-tow-center-covid-19-newsletter-rural-healthcoverage.php. Accessed May 15, 2020.

VanDerslice, J., 2011. Drinking water infrastructure and environmental disparities: Evidence and methodological considerations. American Journal of Public Health 101(S1): S109S114.

Ungar, L., and E. Lucas. 2020. Millions stuck at home with no plumbing, kitchen or space to stay safe. Kaiser Health News, May 12. https://khn.org/news/millions-stuck-at-home-withno-plumbing-kitchen-or-space-to-stay-safe/. Accessed May 15, 2020.
Upshur, R. 2003. The ethics of quarantine. AMA Journal of Ethics 5(11): 393-395.

U.S. Water Alliance. 2019. Closing the water access gap in the United States. DigDeep Right to Water Project. http://uswateralliance.org/sites/uswateralliance.org/files /Closing\%20the\%20Water\%20Access\%20Gap\%20in\%20 the $\% 20$ United\%20States_DIGITAL.pdf

Wallinga, J., M. van Boven, and M. Lipsitch. 2010. Optimizing infectious disease interventions during an emerging epidemic. Proceedings of the National Academy of Sciences 107(2): 923-928.

Warren, R.C., and W.L. Tarver. 2010. A foundation for public health ethics at Tuskegee University in the 21 st century. Journal of Health Care for the Poor and Underserved 21(3): 46-56.

Wedgworth, J.C., and J. Brown. 2013. Limited access to safe drinking water and sanitation in Alabama's Black Belt: A cross-sectional case study. Water Quality, Exposure and Health 5(2): 69-74.

Weinstein, R.S., A.M. Lopez, B.A. Joseph, et al. 2014. Telemedicine, telehealth, and mobile health applications that work: Opportunities and barriers. The American Journal of Medicine 127(3): 183-187.

Wolff, J. 2009. Disadvantage, risk and the social determinants of health. Public Health Ethics 2(3): 214-223.

World Health Organization. 2020. Critical preparedness, readiness and response actions for COVID-19: Interim guidance, 22 March 2020. No. WHO/2019-nCoV/Community_Actions/ 2020.3. https://apps.who.int/iris/bitstream/handle/10665 $/ 331511 /$ Critical\%20preparedness $\% 20$ readiness $\% 20$ and $\% 20$ response \%20actions \%20COVID-10\%202020-03-22 FINAL-eng.pdf. Accessed May 15, 2020.

World Health Organization Writing Group. 2006. Nonpharmaceutical interventions for pandemic influenza, national and community measures. Emerging Infectious Diseases 12(1): 88.

Wynia, M.K. 2007. Ethics and public health emergencies: Restrictions on liberty. The American Journal of Bioethics 7(2): 1-5.

Ye, Z., D.B. Mukamel, S.S. Huang, Y. Li, and H. TemkinGreener. 2015. Healthcare-associated pathogens and nursing home policies and practices: Results from a national survey. Infection Control \& Hospital Epidemiology 36(7): 759-766.

Publisher's note Springer Nature remains neutral with regard to jurisdictional claims in published maps and institutional affiliations. 